\title{
Enhancing Healthful Living Practices Among Rural Women in Nigeria through Non-Formal Education
}

\author{
Loretta Chika Ukwuaba \\ Department of Educational Foundations, \\ Enugu State University of Science and Technology, Enugu, Enugu State
}

\begin{abstract}
The study examined the extent participation in non-formal education programmes enhances healthful living practice among rural women in Nigeria. One research question and one hypothesis guided the study. A survey research design was adopted for the study. Employing stratified random sampling technique, a sample of 1668 rural women from Enugu and Plateau States who participated in the Women for Women International's Renewing Women's Life Skill Education (RENEWLS) Programme was drawn out of which 1558 responded to the study. The instrument used for data collection was a 16-itemed structured questionnaire developed by the researcher. The questionnaire was face validated by three experts, in the field of education, two from adult and continuing education and one from measurement and evaluation reliability co-efficient of 0.83 was obtained using Cronbach Alpha method of determining internal consistency of instrument. The research question was answered using mean and grand mean, while the hypothesis was tested at .05 level of significance using t-test statistics. The result revealed that participation in non-formal education programme enhanced healthful living practices among rural women in Nigeria. There is no significant difference in the mean response of rural women in Enugu and Plateau States on the extent participation in non-formal education enhanced healthful living practices among them. Inculcating RENEWLS education programme into the women education programme of National Policy on Women in Nigeria, extending of the RENEWLS education programme to other states in Nigeria to ensure that majority of rural women in Nigeria were exposed to the programme, were some of the recommendations made.
\end{abstract}

\section{Introduction}

Healthy living behaviours are important factors in promoting health. The World Health
Organization defined health as a state of complete physical, mental and social wellbeing and not merely by absence of disease or infirmity [12]. Eating healthy, being physically active and maintaining a healthy body weight reduce the risk of developing disease and contribute to improved health and quality of life.

Good health is an essential precondition for full enjoyment of all other human rights. Beijing Platform of Action Paragraph 89 and 92 state that, women have the right to the enjoyment of the highest attainable standard of physical and mental health and the right of all women to control all aspects of their health in particular as their own fertility is basic to their empowerment [1]. Good health according to Women for Women International (WFWI) means having a healthy body, but also a healthy mind [11]. Good mental health results from managing the stress levels in your life and being able to contribute to the happiness and wellbeing of loved ones.

Poor health on the other hand is attributed to exposure to diseases, lack of good nutrition, use and abuse of substances such as drugs, tobacco, alcohol etc. Poor health results in loss of productive labour, loss of income and overall wellbeing [11]. WFWI further enumerated the factors that contribute to poor health in the family and community as follows: unhealthy living conditions; lack of clean water, sanitation and safe housing; lack of income to afford nutrition; lack of awareness about the factors that cause poor health; lack of access to health care; lack of affordable healthcare poor lifestyle etc.

In every population group, there exists a gradient in health status from very good to very poor with some individuals experiencing poorer health than others in the society. The poorer group are women particularly rural women as was collaborated by WFWI which asserted that health and well being elude majority of women especially rural women [11]. Within poor households, rural women and children are marginalized in terms of health seeking, nutrition and education [8]. Poor health makes it 
difficult for rural women to participate in the economic, social and cultural life of the communities. In addition rural women as mothers and caretakers bear the greater burden of responsibility in meeting the health, nutritional and social needs of their families in most part of the developing world [2]. For these reasons, development programmes of the decade that have the overall goal of poverty alleviation and improvement of health and nutrition of families view women as more efficient target of their policies [5].

Rural women's knowledge about health, recognizing the factors that cause poor health and understanding the methods of prevention and treatment are useful for all individuals in the family and community. This will go along way in achieving the three United Nations Millennium Development Goals, 4, 5, 6 which focus on reduction of child mortality, improvement of maternal health and combating HIV/AIDS, malaria and other diseases. These Millennium Development Goals could be achieved through an appropriate Non-formal Education Programme for rural women.

Non-formal education is education or training outside the formal school system. Igbo classified NFE as an adult education programme which is most effective for empowerment of women, particularly rural women [4]. Ngwu defined NFE as planned educational activities and training outside the formal school system, for any category of learner, for the purpose of raising their consciousness regarding their social situation and standard of living [6]. Many reports demonstrated that NFE and other organized activities for rural women have positive effects on their health related behaviour. WFWI noted that rural women's participation in health education programmes will enable them to promote household and community wellness, as they will actively seek and utilize health options and illness prevention strategies particularly as it is relates to proper nutrition, hygiene, sanitation and common local maladies [11]. This implies that rural women were now exposed to skills that enables them realize the importance of health as an essential asset. Rural women invariably were able to identify factors that affects women's psychological and reproductive health, health problems affecting women in the community and possible methods of preventing and coping with it.

In their separate studies in Cambodia and Nepal on the relationship between NFE and improved healthful living practices, Holcombe, Murakami \& Samnag and Purdey, Adhkari, Robinson \& Cox, revealed that rural women's participation in health projects is linked to positive changes in their health practices [3] [7]. Also Ukwuaba and Umezulike in a similar study on the perceived impact of Non-formal education on empowerment of rural women in Nigeria, revealed that participation in health education programme enhances healthful living among rural women. The researchers revealed that participants in the project now have improved health knowledge, practices and positive changes in reproductive health practices [9].

In Nigeria as observed by WFWI, rural women have poor knowledge and skills about health precautions and nutrition [11]. These problems resulted in rural women being dependent on others for information on health which may not always be correct. It is within this context that there is a growing commitment to taking action to support rural women in attaining good health through NFE healthful living programme.

The situation of Nigeria rural women spurred Women for Women International (WFWI) a nongovernmental organization to take responsibility of exposing rural women in Nigeria to health education programme using NFE programme titled "Renewing Women's Life Education programme (RENEWLS)" The RENEWLS learning package runs for 12 months and combines right awareness education and vocational skills training. The RENEWLS package was specifically launched to ensure that rural women who participate in the programme will acquire knowledge of healthful living practices through non-formal education programme. WFWI have been educating rural women in two states of Nigeria, Enugu and Plateau States using RENEWLS education programme package. The two states fall within two different geopolitical zones in Nigeria, Enugu in the Southeast and Plateau in the North Central zone. The Nigerian country director of WFWI reported that over 23,000 rural women who participated in the programme in the two states were empowered [10]. No independent assessor known to this researcher has confirmed this report. In the light of this development, the study was carried out to determine whether participation in the RENEWLS education programme enhanced healthful living practices among rural women in Nigeria.

\section{Purpose of the Study}

The purpose of the study was to determine whether participation in non-formal education enhances healthful living practices among rural women in Nigeria. 


\subsection{Research Question}

To what extent has non-formal education enhanced healthful living practices among ruralwomen in Nigeria?

\subsection{Hypothesis}

There is no significant difference between the mean response of rural women in Enugu and Plateau States regarding the extent to which participation in non-formal education enhances healthful living practices among rural-women in Nigeria.

\section{Research Method}

The design of the study was survey research design because, it concentrated on discussing events as they were without any interference on what was observed. The population for the study was 16659 rural women from 26 communities in Nigeria who graduated from the RENEWLS education programme from 2007-2010, 10,484, from Enugu State and 6,175 from Plateau State. Using proportionate stratified sampling technique a total of 1668 rural women from 26 communities in Enugu and Plateau States were randomly sampled and stratified along states

The instrument for data collection was a 16itemed four point scale response option structured questionnaire, with a response format of very great extent (VGE), great extent (GE), low extent (LE), very low extent (VLE) and a numerical value of 4, 3, 2 and 1 respectively. The instrument was validated by three experts in the field of education, one from measurement and evaluation and two from Adult education. Based on their comments, some items were reconstructed. The reliability of the instrument was determined using Cronbach's alpha formula and internal consistency reliability co-efficient of 0.83 was obtained. The questionnaire was administered to the RENEWLS programme graduates during their monthly group meetings in their various communities with the help of trained research assistants. The questionnaire served as an interview schedule where respondents experience difficulty in reading and writing.

The research question was analyzed using mean and grand mean, while the hypothesis was tested using t-test statistics at .05 level of significance. The decision rule was as follow: any item with mean 2.50 and above was accepted which shows that participation in RENEWLS education programme enhances healthful living practices among rural women in Nigeria to a great extent, while those below 2.50 were not accepted, which indicates that the programme enhances healthful living practices to a low extent. Where the calculated t-value was equal to or greater than the critical value of $t$, the null hypothesis was rejected, but if less than the critical $t$ value, it was not rejected.

\section{Results}

The results of the data analysis were presented in tables according to research question and hypothesis.

\subsection{Research Question}

To what extent has participation in RENEWLS education programme enhances healthful living practices among rural women in Nigeria?

Table 1. Mean Rating of Rural Women in Nigeria on the Extent to Which Participation in RENEWLS Education Programme Enhances their Healthful Living Practices.

$\mathrm{n}=1558$

\begin{tabular}{|c|c|c|c|c|c|}
\hline \multirow{2}{*}{$\begin{array}{l}\mathbf{S} / \\
\mathbf{N}\end{array}$} & \multirow[b]{2}{*}{ Items } & \multicolumn{2}{|c|}{ Enugu State } & \multicolumn{2}{|c|}{$\begin{array}{l}\text { Plateau } \\
\text { State }\end{array}$} \\
\hline & & $\overline{\mathbf{x}}$ & & $\overline{\mathbf{x}}$ & SD \\
\hline & $\begin{array}{l}\text { My participation } \\
\text { in RENEWLS } \\
\text { education } \\
\text { programme has } \\
\text { made me to: }\end{array}$ & & & & \\
\hline 1 & $\begin{array}{l}\text { Insist on eating } \\
\text { balanced diet in } \\
\text { my family. }\end{array}$ & 2.93 & 1.08 & 2.81 & 1.11 \\
\hline 2 & $\begin{array}{l}\text { Practice general } \\
\text { hygiene }\end{array}$ & 3.15 & 0.92 & 2.99 & 0.94 \\
\hline 3 & $\begin{array}{l}\text { Practice family } \\
\text { planning }\end{array}$ & 3.25 & 0.87 & 3.21 & 0.89 \\
\hline 4 & $\begin{array}{l}\text { Know the } \\
\text { importance of } \\
\text { rest. }\end{array}$ & 2.90 & 0.99 & 2.72 & 1.07 \\
\hline 5 & $\begin{array}{l}\text { Plan out my } \\
\text { time to reduce } \\
\text { stress }\end{array}$ & 2.88 & 1.02 & 2.80 & 1.05 \\
\hline 6 & $\begin{array}{l}\text { Know about all } \\
\text { the infections } \\
\text { diseases in my } \\
\text { environment }\end{array}$ & 3.18 & 0.85 & 3.10 & 0.89 \\
\hline 7 & $\begin{array}{l}\text { Take appropriate } \\
\text { measures to } \\
\text { avoid contacting } \\
\text { the infectious } \\
\text { diseases. }\end{array}$ & 3.24 & 0.98 & 3.20 & 0.91 \\
\hline 8 & $\begin{array}{l}\text { Know about } \\
\text { different } \\
\text { sexually } \\
\text { transmitted }\end{array}$ & 3.08 & 0.98 & 3.06 & 1.00 \\
\hline
\end{tabular}




\begin{tabular}{|c|c|c|c|c|c|}
\hline & diseases. & & & & \\
\hline 9 & $\begin{array}{l}\text { Attend anti-natal } \\
\text { clinics when } \\
\text { pregnant. }\end{array}$ & 3.19 & 0.89 & 3.11 & 0.90 \\
\hline 10 & $\begin{array}{l}\text { Discuss } \\
\text { reproductive } \\
\text { issues } \\
\text { confidently with } \\
\text { my husband. }\end{array}$ & 2.90 & 1.00 & 2.82 & 1.02 \\
\hline 11 & $\begin{array}{l}\text { Keep my } \\
\text { surrounding } \\
\text { clean. }\end{array}$ & 3.28 & 0.79 & 3.20 & 0.82 \\
\hline 12 & $\begin{array}{l}\text { Ensure that } \\
\text { every member } \\
\text { of my family } \\
\text { observe general } \\
\text { hygiene rules. }\end{array}$ & 3.15 & 0.86 & 3.10 & 0.88 \\
\hline 13 & $\begin{array}{l}\text { Enlighten my } \\
\text { children on } \\
\text { reproductive } \\
\text { health issues. }\end{array}$ & 3.09 & 1.05 & 2.93 & 1.06 \\
\hline 14 & $\begin{array}{l}\text { Give my } \\
\text { children sex } \\
\text { education. }\end{array}$ & 2.94 & 1.03 & 2.88 & 1.05 \\
\hline 15 & $\begin{array}{l}\text { Always go to } \\
\text { qualified } \\
\text { medical } \\
\text { personnel for } \\
\text { health issues. }\end{array}$ & 2.81 & 1.07 & 2.73 & 1.09 \\
\hline 16 & $\begin{array}{l}\text { Stop self } \\
\text { medication. }\end{array}$ & 2.80 & 1.03 & 2.70 & 1.04 \\
\hline & Mean & 3.05 & & 2.96 & \\
\hline & Grand Mean & \multicolumn{4}{|c|}{3.01} \\
\hline & $\begin{array}{l}\text { Standard } \\
\text { deviation }\end{array}$ & & 0.96 & & $\begin{array}{l}0.9 \\
8\end{array}$ \\
\hline
\end{tabular}

The table shows that a grand mean of 3.01 was obtained for all the 16 items indicating that participation in the RENEWLS education programme has to a high extent enhanced healthful living practices among rural women in Nigeria.

\subsection{Testing of hypothesis}

There is no significant difference between the mean response of rural women in Enugu and their counterpart in Plateau State on the extent to which participation in RENEWLS education programme enhances their healthful living practices.

Table 2. T-Test of Difference Between the Mean Response of Rural Women in Enugu and their Plateau State Counterpart Regarding the Extent to which Participation in RENEWLS Education Programme Enhances their Healthful Living Practices.

\begin{tabular}{|c|c|c|c|c|c|c|c|}
\hline $\begin{array}{c}\text { Locati } \\
\text { on of }\end{array}$ & $\mathbf{n}$ & $\overline{\mathbf{x}}$ & SD & $\mathbf{d f}$ & t.cal & $\begin{array}{c}\text { t- } \\
\text { crit. }\end{array}$ & $\begin{array}{c}\text { Deci } \\
\text { sion }\end{array}$ \\
\hline
\end{tabular}

\begin{tabular}{|l|l|l|l|l|l|l|l|}
\hline $\begin{array}{c}\text { Rural } \\
\text { women }\end{array}$ & & & & & & & \\
\hline $\begin{array}{l}\text { Enugu } \\
\text { State }\end{array}$ & 1030 & 3.05 & 0.96 & 1556 & 1.73 & 1.96 & $\begin{array}{l}\text { Do } \\
\text { not } \\
\text { Reje } \\
\text { ct } \mathrm{H}_{0}\end{array}$ \\
\hline $\begin{array}{l}\text { Plateau } \\
\text { State }\end{array}$ & 528 & 2.96 & 0.98 & & & & \\
\hline
\end{tabular}

Table 2 shows that the calculated t-value at 0.5 level of significance and 1556 degree of freedom is 1.73 while the critical t-value is 1.96 . Since the calculated value of $t$ is less than the critical or table value, the null hypothesis is therefore not rejected. This means that no significant difference exists between the mean ratings of rural women in Enugu and Plateau States regarding the extent to which participation in RENEWLS education programme has enhanced their healthful living practices.

\section{Discussion of Findings}

Results from data analysis revealed that participation in the RENEWLS education programme has to a large extent enhanced healthful living practices among rural women in Nigeria. The study revealed that with the acquisition of skills on healthful living practices, their health status improved. This is evidenced in their indication that women now practice general hygiene, eat balanced diet, practice family planning, know about different diseases and their prevention. The study also revealed that skills acquired in the NFE programme gave rural women confidence to discuss reproductive health issues with their husbands and children. These findings are line with the assertion of WFWI, that rural women's participation in health education programme enabled them to promote household and community wellness, as they will actively seek and utilize healthcare options and illness prevention strategies particularly as it is related to proper nutrition, hygiene, sanitation and common maladies [10]. In agreement with the findings also Holcombe, Murakami \& Samnag, and Purdey, Adhakari, Robinson \& Cox and Ukwuaba \& Umezulike in their respective studies on relationship between NFE and improved health practices revealed that women who participated in such programmes have improved health knowledge, practices and positive changes in reproductive health, feel empowered and learn to overcome shyness [3] [7] [9].

The null hypothesis indicated that significant difference does not exist between the mean response of rural women in Enugu and their counterparts in Plateau State, regarding the extent to which the RENEWLS education programme enhances healthful living among them. This implies that participants from the states imbibed improved health 
knowledge and practices. The result of this study may be based on the fact that good health is an essential precondition for full enjoyment of all other human rights and has a positive impact on income and well being of the individual family and community as a whole. Rural women who participated in the programme practiced and encouraged their family members to practice health tips to be healthy in order to participate both in the economic and social life of the community, because health is wealth.

\section{Conclusion}

The findings show that participation in RENEWLS education programme has enhanced healthful living practices among rural women in Nigeria. The mean rating of rural women from the two states studied on enhancing healthful living practice among rural women did not differ significantly due to the general acceptance that good health will improve both the social and economic life of their families. The findings from this study invariably indicate that good health practices for rural women can be achieved through non-formal education.

\section{Recommendations}

Based on the findings of the study, the following recommendations were made:

1. The RENEWLS education programme should be adopted as a means of implementing government policy on adult and non-formal education and ensure that women in all communities in Nigeria participate in the programme to facilitate the realization of fourth, fifth and sixth Millennium. Development Goals, which emphasized; reduction in child mortality, improvement of maternal health, and combating HIV/AIDs, malaria and other disease.

2. The RENEWLS education programme should be inculcated into women's education curriculum as presently stipulated in the National Policy on Education in Nigeria.

3. RENEWLS education programme should be extended to other states in Nigeria to ensure that majority of rural women in Nigeria were exposed to the programme

\section{References}

[1] Beijing Platform of Action (1995). Fourth world conference on women, Beijing, China: United Nations.

[2] Desai, S. and Jain, D. (1992). Maternal employment and change in family dynamics: The social context of women's work in South India, Washington DC: International centre for research on women.

[3] Holcombe, S. Murakari, H. and Samnang, P. (1996). Evaluation report on USAID funded education, Cambodia non-formal education project draft: World Education Inc.

[4] Igbo, R.O. (2008) Adult education and Nigeria development in a globalised world. In R.O. Igbo (ed), Contemporary adult education: An inclusive approach, Enugu: Cidjap press.

[5] Mariyoux, L. (2003). Sustainable learning for women's empowerment: Way forward in micro finance, New Delhi: Sam Skriti.

[6] Ngwu, P.N.C. (2006). Non-formal education: concepts and practices, Enugu: Fulladu.

[7] Purdey, A. Adhikari, G. Robinson, S. and Cox, P. (1994). Preparatory health development in rural Nepal: clarifying the process of community empowerment, Health education quarterly, 21(3)

[8] Sen, A.K. (1995). Gender and cooperative conflict, New York: Oxford University Press.

[9] Ukwuaba, L.C. and Umezulike A.N. (2012). Perceived impact of women for women international non-formal learning programme on rural women in Nigeria, Preconference in proceeding of American Association for Adult and Continuing Education (AAACE) 61st Annual Conference. Commission ofr International Adult Education (CIAE). Las Vegas, USA. P.158 - 167.

[10] Women for Women Internation (2010). Nigeria field update, support women of Nigeria http://www.womenforwomen.org/globalinitiativeshelping-women/Nigeria-community-direct.1.

[11] Women for Women Internation (2009). A woman's world: Women for Women International renewing women's life skill training manual, Washington DC: Author.

[12] World Health Organization (2009), Human Development Report, Geneva: Author 